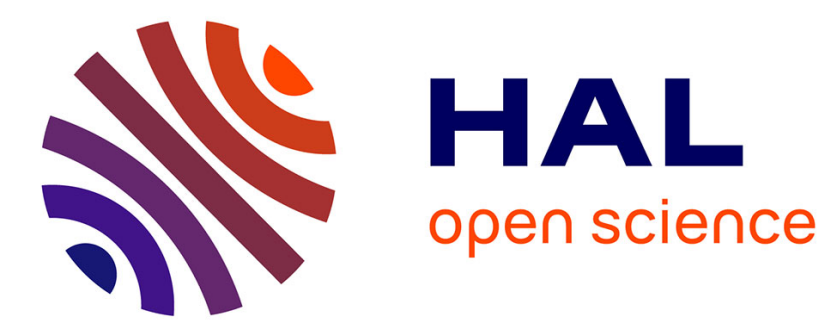

\title{
Autolysis of Lactobacillus helveticus and Propionibacterium freudenreichii in Swiss cheeses: First evidence by using species-specific lysis markers
}

Florence Valence, R. Richoux, Anne Thierry, A. Palva, Sylvie S. Lortal

\section{- To cite this version:}

Florence Valence, R. Richoux, Anne Thierry, A. Palva, Sylvie S. Lortal. Autolysis of Lactobacillus helveticus and Propionibacterium freudenreichii in Swiss cheeses: First evidence by using speciesspecific lysis markers. Journal of Dairy Research, 1998, 65 (4), pp.609-620. hal-02694510

\author{
HAL Id: hal-02694510 \\ https: / hal.inrae.fr/hal-02694510
}

Submitted on 1 Jun 2020

HAL is a multi-disciplinary open access archive for the deposit and dissemination of scientific research documents, whether they are published or not. The documents may come from teaching and research institutions in France or abroad, or from public or private research centers.
L'archive ouverte pluridisciplinaire HAL, est destinée au dépôt et à la diffusion de documents scientifiques de niveau recherche, publiés ou non, émanant des établissements d'enseignement et de recherche français ou étrangers, des laboratoires publics ou privés. 


\title{
Autolysis of Lactobacillus helveticus and Propionibacterium freudenreichii in Swiss cheeses: first evidence by using species-specific lysis markers
}

\author{
BY FLORENCE VALENCE, ROMAIN RICHOUX*, ANNE THIERRY, \\ AIRI PALVA $\dagger$ AND SYLVIE LORTAL $\ddagger$ \\ INRA, Laboratoire de Recherches de Technologie Laitière, 65 rue de St Brieuc, \\ F-35042 Rennes Cédex, France \\ * Institut Technique du Gruyère, 73 rue de St Brieuc, F-35062 Rennes Cédex, France \\ $\dagger$ Agricultural Research Centre, Food Research Institute, FIN-31600 Jokioinen, \\ Finland
}

(Received 24 November $199 \%$ and accepted for publication 25 February 1998)

Summary. Lactobacillus helveticus and Propionibacterium freudenreichii are essential starters in Swiss cheesemaking and the release of their intracellular enzymes through autolysis could significantly influence ripening. To provide evidence of this lysis, cheese made from microfiltered thermized milk inoculated with $L b$. helveticus ITGLH77, Prop. freudenreichii ITGP23 and a commercial Streptococcus thermophilus was assayed. Starter viability was determined and lysis was monitored during ripening by protein analysis with SDS-PAGE of aqueous cheese extracts and by immunoblot detection of intracellular proteins : dipeptidase (PepD) for Lb. helveticus and methylmalonyl coenzyme A mutase for Prop. freudenreichii. We verified that the species specificity of these lysis markers was towards the cytoplasms of all the species currently used in Swiss cheese. Lb. helveticus exhibited an almost complete loss of viability $(99.9 \%)$ from the beginning of ripening in the cold room; concomitantly PepD appeared in the cheese extracts and was detected until the end of ripening. Damaged $L b$. helveticus cells were also visualized by scanning electron microscopy. In addition, free PepD was also successfully detected in commercial Swiss-related cheeses. All these results clearly demonstrated the autolysis of Lb. helveticus in Swiss cheese. Prop. freudenreichii ITGP23 grew during warm room ripening and no loss of viability was detected after maximal growth $\left(10^{9} \mathrm{cfu} / \mathrm{g}\right.$ cheese). Free methylmalonylcoenzyme A mutase was detected at the end of ripening during cold storage, when the cheese extracts were concentrated 20 -fold, demonstrating that the autolysis of Prop. freudenreichii was tardy and limited.

The contribution of lactic acid bacteria to cheesemaking has long been considered to be due exclusively to the presence of live microorganisms producing lactic acid and proteolytic enzymes. Nevertheless, it seems increasingly obvious that lactic acid bacteria starters continue to influence ripening markedly even after their death by releasing their numerous intracellular peptidases and esterases through autolysis (Hansen, 1941; Law et al. 1974). Autolysis of lactococci has been clearly demonstrated in Cheddar (Wilkinson et al. 1994a,b; Crow et al. 1995 ) and Saint-Paulin cheese (Chapot-Chartier et al. 1994). As expected, the extent of lysis was shown to have a

\footnotetext{
\$ For correspondence.
} 
direct effect on the extent of proteolysis (Crow et al. 1995b; O'Donovan et al. 1996 ; Kawabata et al. 1997). For these reasons, autolysis is now regarded as the ratelimiting step of proteolysis in hard and semi-hard cheeses.

Swiss-type cheeses are of obvious economic importance since $\sim 850000$ tonnes of these varieties are produced every year all around the world (Syndicat Interprofessionel du Gruyère Français, 1997). Their ripening requires several weeks and a decrease of viability of thermophilic lactic acid bacteria starters has been frequently described, suggesting that autolysis occurs (Demeter et al. 1953; Accolas et al. 1978; Demarigny et al. 1996; Thierry et al. 1998). Several species, including Streptococcus thermophilus, Lactobacillus helveticus, Lb. delbrueckii subsp. lactis and Propionibacterium freudenreichii, are used together in order to carry out the acidification step as well as the ripening process (Langsrud \& Reinbold, 1973). Autolysis of these species has been studied in growth media and buffers, leading to a better knowledge of their autolysins (Sandholm \& Sarimo, 1981; Lortal et al. 1997a), but very few assays have been carried out in cheese-like media, and most of these were conducted with Lb. helveticus. Ohmiya \& Sato (1970) followed the autolysis of Lb. helveticus in an aseptic rennet curd and Bie \& Sjöström $(1975 a, b)$ did the same in a casein liquid substrate and in semi-hard cheeses. Both groups monitored lysis by the release of DNA into the curd but encountered detection problems due to DNA degradation. Recently, damaged cells of Lb. helveticus and Prop. freudenreichii were visualized in Grana by scanning electron microscopy, indicating that both species underwent autolysis in this cheese (Bottazzi, 1993; Cappa et al. 1997).

The aim of this work was to investigate whether Lb. helveticus and Prop. freudenreichii undergo autolysis in Swiss cheese during processing and ripening. They were chosen from the different species inoculated because of their efficient cytoplasmic peptidase and esterase activity (Dupuis \& Boyaval, 1993; Prost \& Chamba, 1994; Sasaki et al. 1995). To study the autolysis, species-specific lysis markers had to be developed first because several species are present in Swiss cheese, growing and dying simultaneously. Cheeses were made on a small scale and the autolysis of both species was demonstrated using immunological detection of the lysis markers in aqueous cheese extracts.

MATERIALS AND METHODS

Organisms and culture conditions

Lb. helveticus ITGLH77 (LH77) and ITGLH1 (LH1) and Prop. freudenreichii ITGP23 (P23) are commercial starters from the Institut Technique du Gruyère collection. LH77 and P23 were selected on the basis of their high autolysis in buffers as described by Valence \& Lortal (1995) for Lb. helveticus and by Lemée et al. (1994b) for Prop. freudenreichii. Str. thermophilus was a commercial starter (TA060) from Texel (F-86220 Dangé Saint-Romain, France). Lb. delbrueckii subsp. lactis CIP101028 was from the Institut Pasteur collection (F-75724 Paris Cédex 15, France) and Lactococcus lactis subsp. lactis CNRZ 144 was obtained from the Centre National de la Recherche Zootechnique (F-78352 Jouy-en-Josas, France).

Strains were stored at $-80{ }^{\circ} \mathrm{C}$ in MRS broth (Difco, Detroit, MI 48232, USA) for Lb. helveticus and Lb. lactis, in sodium lactate broth (Malik et al. 1968) for Prop. freudenreichii and in M17 broth (Biokar 088, F-60000 Beauvais, France) for Str. thermophilus and Lc. lactis. The media were supplemented with $150 \mathrm{ml}$ glycerol/l prior to freezing. For propagating the strains, the appropriate media without glycerol were used and growth was monitored by measuring $A_{650}$. 
For cheese trials, cultures were revived from frozen stocks first by a transfer in reconstituted skim milk (100 g Lait G/l; Standa Industrie, F-14050 Caen, France) at $2 \mathrm{ml}$ inoculum/l until lactic acid as measured by Dornic acidity reached $7.5 \mathrm{~g} / \mathrm{l}$, followed by a second transfer on Phagex commercial medium (Standa Industrie) at $100 \mathrm{ml}$ inoculum/l until lactic acid reached $9 \cdot 5 \mathrm{~g} / \mathrm{l}$ for $L b$. helveticus, or by two consecutive transfers in sodium lactate broth at $2 \mathrm{ml}$ inoculum/l until $A_{650}$ reached 1 for Prop. freudenreichii.

Preparation of crude cytoplasm for determination of lysis marker specificity

Cells were harvested during the exponential growth phase by centrifugation at $7000 \mathrm{~g}$ for $20 \mathrm{~min}$ and washed twice in cold distilled water. The pellet was resuspended in a volume of cold water $1 / 15$ th that of the initial volume of the culture, then subjected to treatment in a French Press apparatus at $4{ }^{\circ} \mathrm{C}$ and $138 \mathrm{MPa}$ for $5 \mathrm{~min}$ (one run) for Lb. helveticus and Lb. lactis and at $138 \mathrm{MPa}$ for $10 \mathrm{~min}$ (two runs) for Prop. freudenreichii, Str. thermophilus and Lc. lactis. Suspensions were centrifuged at $40000 \mathrm{~g}$ for $30 \mathrm{~min}$ to eliminate unbroken cells and cell walls. The supernatants represented crude cytoplasms, and were stored at $-18^{\circ} \mathrm{C}$ until used.

\section{Cheese manufacture}

Small scale experimental Swiss cheeses were made from $10 \cdot 3 \mathrm{~kg}$ thermized and microfiltered milk by a standard procedure described previously (Buisson et al. 1987) with the following modifications. The starter was composed of Str. thermophilus, Lb. helveticus ITGLH77 and Prop. freudenreichii ITGP23; no Lb. lactis species were added. Cheeses were divided into four pieces $(4 \times 200 \mathrm{~g})$ before waxing and were ripened at $11^{\circ} \mathrm{C}$ (cold room) for $21 \mathrm{~d}$, at $24{ }^{\circ} \mathrm{C}$ (warm room) for $48 \mathrm{~d}$ and at $4{ }^{\circ} \mathrm{C}$ (cold storage) for $15 \mathrm{~d}$. From a single batch of milk three repetitions were carried out on three successive days. Three cheeses were produced per day, in order to provide 12 pieces of cheese for sampling. Samples were taken just after pressing (day 0), after brining (day 1) at the middle (day 16) and end (day 22) of the time in the cold room, at the middle (day 45) and end (day 69 ) of the time in the warm room, and after 1 week (day 76 ) and 3 weeks (day 92) cold storage.

\section{Chemical analysis of cheeses}

Total solids (International Dairy Federation, 1982), fat (Heiss, 1961) and NaCl (International Dairy Federation, 1988) contents were determined in the ripened cheese on day 69. During ripening (days 22, 33, 40, 47 and 69) lactate (kit from Boehringer, D-68298 Mannheim 31, Germany), propionate, acetate (Berdagué, 1986) and cheese volume (Richoux \& Kerjean, 1995) were monitored.

\section{Aqueous cheese extracts}

Standard extracts were obtained essentially as described by Kuchroo \& Fox (1982) with the following modifications. Each cheese sample $(20 \mathrm{~g})$ was homogenized with an Ultra-Turrax disperser (Bioblock, F-67403 Illkirch, France) for 2 min in $80 \mathrm{ml}$ of water and the suspension was held at $38^{\circ} \mathrm{C}$ for $20 \mathrm{~min}$ before centrifugation at $3000 \mathrm{~g}$ and $4{ }^{\circ} \mathrm{C}$ for $15 \mathrm{~min}$. After removal of the upper solid fat layer the supernatant was filtered through Whatman no. 1 paper and then a $0.45 \mu \mathrm{m}$ acetate filter (Sartorius, F-91127 Palaiseau, France). Aqueous cheese extracts were stored at $-18{ }^{\circ} \mathrm{C}$ until the SDS-PAGE and immunoblotting assays were carried out.

For gentle extracts, each grated cheese sample $(1.5 \mathrm{~g})$ was ground manually in 
$6 \mathrm{ml}$ distilled water in a filter stomacher bag (Humeau, F-44240 Treillière, France) at $20^{\circ} \mathrm{C}$ for $5 \mathrm{~min}$. The supernatant was filtered through a $0.45 \mu \mathrm{m}$ acetate filter (Sartorius). Gentle aqueous cheese extracts were stored at $-18{ }^{\circ} \mathrm{C}$ until used.

Starter viability

A $10 \mathrm{~g}$ cheese sample was homogenized with a Waring Blendor (Prolabo, F-94126 Fontenay-sous-Bois, France) once for $20 \mathrm{~s}$ at maximal speed, then twice for $10 \mathrm{~s}$ at minimal speed in $90 \mathrm{~g}$ trisodium citrate solution $(20 \mathrm{~g} / \mathrm{l})$. The viability of starter lactobacilli in cheese was measured by plating serial dilutions of samples on MRS ( $\mathrm{pH} 5 \cdot 4)$ agar and incubating at $37^{\circ} \mathrm{C}$ for $48 \mathrm{~h}$. Prop. freudenreichii cells were enumerated on the selective medium Pal Propiobac (Standa Industrie) after incubation at $30^{\circ} \mathrm{C}$ for $5 \mathrm{~d}$, and Str. thermophilus cells on M17 agar plates (Biokar 088 ) after incubation at $43{ }^{\circ} \mathrm{C}$ for $16 \mathrm{~h}$. Non-starter lactic acid bacteria were enumerated on $\mathrm{FH}$ agar plates (Isolini et al. 1990) after incubation at $37^{\circ} \mathrm{C}$ for $3 \mathrm{~d}$. Anaerobic growth conditions (Anaerocult A; Merck, F-94736 Nogent-sur-Marne, France) were used for all species studied and results were expressed as cfu/g cheese.

Genomic DNA preparation and pulsed field gel electrophoresis

In order to verify the identities of the strains enumerated on MRS ( $\mathrm{pH} 5 \cdot 4)$ agar and on Pal Propiobac, 20 colonies were randomly picked from 25-50 colonies on count plates on day 16 for Lb. helveticus and day 69 for Prop. freudenreichii, then subjected to genomic macrorestriction profile analysis according to the procedure of Lortal et al. (1997b) and Lemée et al. (1994b) for Lb. helveticus and Prop. freudenreichii respectively. Macrorestriction profiles obtained were compared with those of LH77 and P23 strains.

\section{Scanning electron microscopy}

Cheese samples were taken for electron microscopy at days 22 and 69. Two $1 \times 1 \times 3 \mathrm{~mm}$ pieces were cut from the internal portion of the cheese and fixed in glutaraldehyde $(2.5 \mathrm{ml} / \mathrm{l}, \mathrm{pH} 7 \cdot 2)$ at $4{ }^{\circ} \mathrm{C}$ for $48 \mathrm{~h}$. Samples were washed twice in 25 mu-cacodylate buffer, $\mathrm{pH} 7 \cdot 5$, then fixed in $10 \mathrm{~g}$ osmium tetroxide/ 1 at $4{ }^{\circ} \mathrm{C}$ for $15 \mathrm{~h}$ followed by dehydration in alcohol at 100, 250, 500, 750 and $950 \mathrm{ml} / \mathrm{l}$ successively. The sample was critical point dried in $\mathrm{CO}_{2}$, mounted on an aluminium stub and coated with $15 \mathrm{~nm}$ gold. Microscopy was on a Philips XL20 scanning electron microscope at an acceleration voltage of $15 \mathrm{kV}$.

SDS-PAGE analysis of total protein content of aqueous cheese extracts

SDS-PAGE was carried out as described by Valence \& Lortal $(1995)$ at $20^{\circ} \mathrm{C}$ with an SDS-polyacrylamide $(140 \mathrm{~g} / \mathrm{l})$ separating gel, $\mathrm{pH} 8 \cdot 8$ and a constant voltage of $180 \mathrm{~V}$. Samples were mixed with an equal volume of Laemmli buffer $(62.5 \mathrm{~mm}$-Tris $\mathrm{HCl}, \mathrm{pH} 6 \cdot 8$ containing $100 \mathrm{ml}$ glycerol/l, $20 \mathrm{~g}$ SDS/l and $50 \mathrm{ml}$ 2-mercaptoethanol/l) and boiled for 2 min (Laemmli, 1970); $20 \mu \mathrm{l}$ of each sample was loaded on the gel.

Detection of the species-specific lysis marker using immunoblot assay

A $53.4 \mathrm{kDa}$ dipeptidase (PepD) was selected as specific lysis marker for $L b$. helveticus. This peptidase has been shown to be intracellularly located and its DNA and amino acid sequences show no homology with any of the numerous lactic acid bacterial peptidases described so far (Vesanto et al. 1996). The sample used for immunization had been overexpressed in Escherichia coli, purified and immunized in an active form (octamer form). Immunization was with three injections ( $20 \mu \mathrm{g}$ antigen per injection) per rabbit, and immunization time was 6 weeks. 
In the case of Prop. freudenreichii, the finding of a specific lysis marker was much easier, mainly because that species is phylogenetically very far from the lactobacilli and streptococci involved in Swiss cheesemaking. An intracellular enzyme required in the metabolism of propionic acid, i.e. the methylmalonyl coenzyme A mutase (MMCoA), was selected. This enzyme comprises two subunits, $\alpha$ and $\beta$, of 62 and $70 \mathrm{kDa}$ respectively (Marsh et al. 1989). MMCoA has been reported only in propionibacteria and in animal tissues (Kellermeyer et al. 1964). From $400 \mu \mathrm{g}$ of Prop. shermanii MMCoA from recombinant Esch. coli, polyclonal antibodies against MMCoA were produced by four successive intradermic injections of $50 \mu \mathrm{g}$ MMCoA which were carried out on days 0, 14, 28 and 56 in two rabbits (Eurogentec, B-4102 Seraing, Belgium).

Samples were subjected to SDS-PAGE and then transblotted on to a nitrocellullose sheet $(0.45 \mu \mathrm{m}$ pore size : Millipore, F-78051 Saint-Quentin-en-Yveline, France) as described by Towbin et al. (1979). PepD and MMCoA were detected with rabbit sera anti-PepD and anti-MMCoA mutase respectively. Horseradish peroxidase-conjugated goat anti-rabbit IgG (Sigma, St Louis, MO 63178, US) was used as the secondary antiserum with 4-chloro-1-naphthol and $\mathrm{H}_{2} \mathrm{O}_{2}$ substrates.

\section{RESULTS}

Specific lysis markers for Lactobacillus helveticus and Propionibacterium freudenreichii

Immunoblotting analysis of the cytoplasms of Lb. helveticus strains LH77 and LH1 with polyclonal PepD antiserum confirmed the presence of PepD protein of the expected size also in these strains (Fig. 1). Fig. 1 provides evidence that the polyclonal antibodies against PepD did not cross react with cytoplasmic extracts of Str. thermophilus, Lc. lactis and Prop. freudenreichii. For Lb. lactis a cross reacting protein was clearly detected but with a molecular mass slightly lower (51 kDa). A mixture of cytoplasmic extracts from Lb. helveticus and Lb. lactis $(1: 1)$ produced two close bands that could be distinguished (Fig. 1, lane 7), further confirming the specificity of PepD and its validity as a lysis marker. However, in the course of the cheese assays, the species Lb. lactis was omitted in order to avoid any doubt about the immunoblot detection of PepD.

In order to establish the sensitivity of PepD immunodetection, different quantities of total cytoplasmic proteins (from 1 to $34 \mu \mathrm{g}$ ) were analysed by immunoblotting, and showed that a quantity of PepD as low as $2 \cdot 1 \mu \mathrm{g}$ could be detected. For $>17 \mu \mathrm{g}$ protein, the intensity of the signal detected remained constant (results not shown).

A cytoplasmic extract of Prop. freudenreichii P23 subjected to immunoblot analysis with rabbit serum anti-MMCoA made it possible to detect the two $\alpha$ and $\beta$ subunits of the expected sizes (Fig. 2). A cytoplasmic extract of Lb. helveticus did not cross react with serum anti-MMCoA (results not shown). The sensitivity of the assay was determined and showed that $1.6 \mu \mathrm{g}$ per lane of the total cytoplasmic proteins of Prop. freudenreichii was sufficient to achieve the detection of the two subunits of the MMCoA; the signal detected for the $\alpha$ subunit was more intense than that for the $\beta$ subunit. For $>6 \cdot 6 \mu \mathrm{g}$ protein, the intensity of the signal detected remained constant (Fig. 2). 


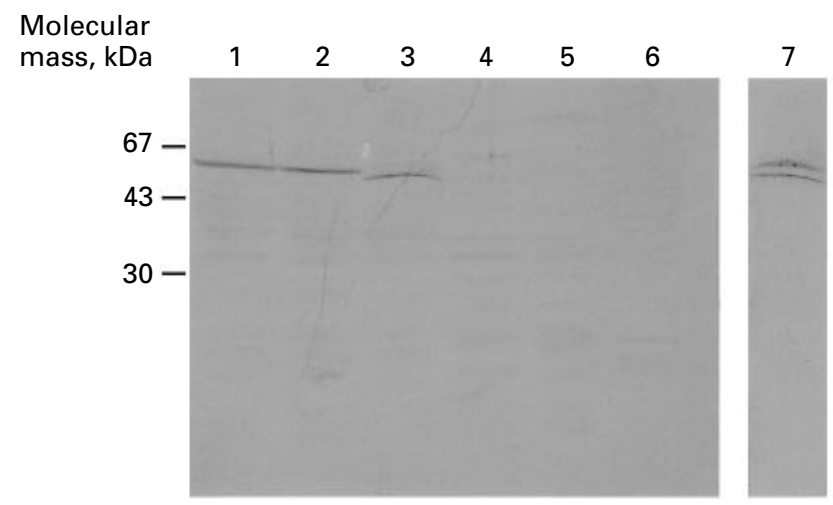

Fig. 1. Specificity of dipeptidase for use as a Lactobacillus helveticus lysis marker. Immunoblot of cytoplasm from various species used in Swiss cheesemaking using serum anti-dipeptidase: lane 1, $L b$. helveticus LH77; lane 2, Lb. helveticus LH1; lane 3, Lb. delbrueckii subsp. lactis; lane 4, Streptococcus thermophilus; lane 5, Lactococcus lactis subsp lactis; lane 6, Propionibacterium freudenreichii; lane 7, $1: 1$ mixture (v/v) of Lb. helveticus LH77 and Lb. delbrueckii subsp. lactis. Molecular masses of standard proteins are indicated on the left.

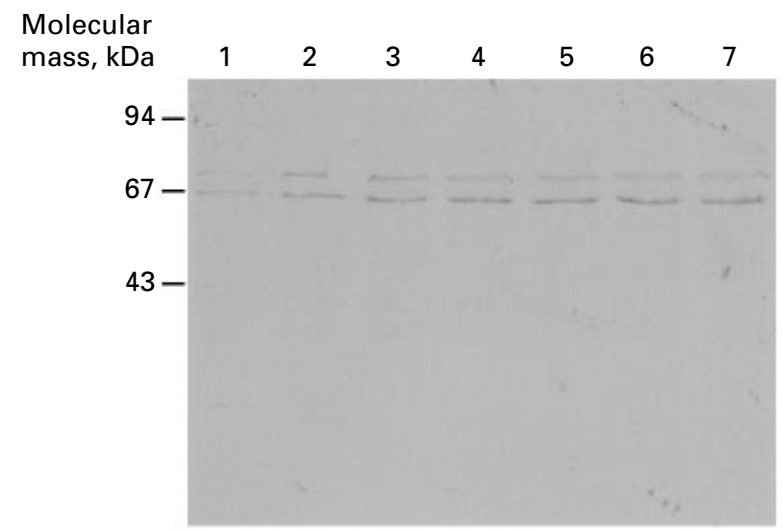

Fig. 2. Sensitivity of methylmalonyl coenzyme A mutase detection by immunoblotting estimated by loading increasing quantities of Propionibacterium freudenreichii P23 cytoplasmic proteins : lane 1, 1·6; lane $2,3 \cdot 2$; lane $3,6 \cdot 6$; lane $4,9 \cdot 6$; lane 5,13 ; lane 6,19 and lane $7,26 \mu \mathrm{g}$.

\section{Chemical analysis of the cheeses}

The chemical analyses were in agreement with previous values for Swiss cheeses prepared on a small scale (Buisson et al. 1987) and on an industrial scale (Steffen et al. 1993). During ripening, as expected, the depletion of lactate was concomitant with the production of acetate and propionate and was completed on day 47 .

\section{Viability of starter and non-starter bacteria during ripening}

Maximal numbers of $L b$. helveticus cells were reached at the end of the pressing (day 0$)$ followed by a decrease in numbers, moderately (0.3 log unit) during brining (day 1) and significantly (3 log units) during cold room ripening. At the end of ripening, Lb. helveticus was hardly detectable ( $<100 \mathrm{cfu} / \mathrm{g}$ cheese; Fig. 3). At day 16 the macrorestriction profiles of 20 colonies, randomly sampled during the enumeration of starter, were shown to be identical to the reference profile of $L b$. helveticus LH77. The viability of Str. thermophilus decreased in the same way as $L b$. helveticus, reaching $10^{4} \mathrm{cfu} / \mathrm{g}$ at the end of the ripening. The viable count of Prop. 


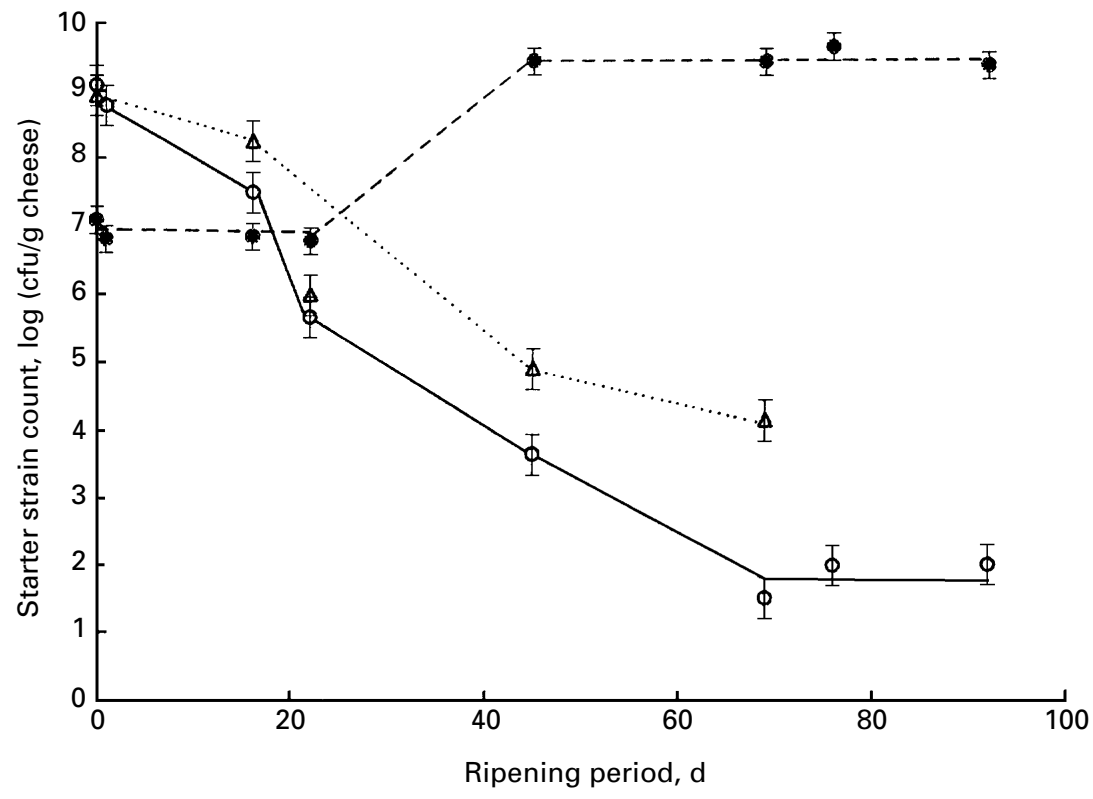

Fig. 3. Counts of starter strains in experimental cheeses during ripening: $\bigcirc$, Lactobacillus helveticus LH77; - Propionibacterium freudenreichii; $\triangle$, Streptococcus thermophilus. Values are means from three trials with SD indicated by vertical bars.
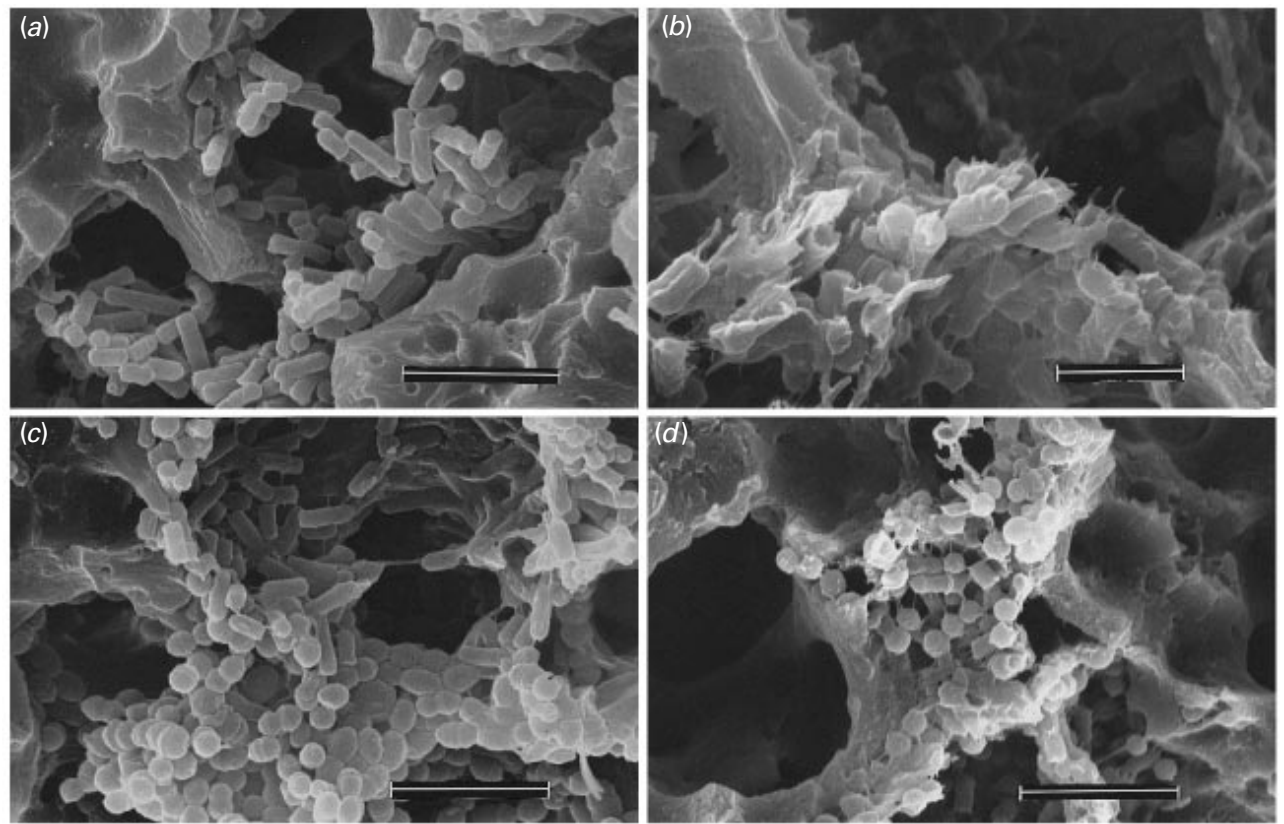

Fig. 4. Electron photomicrographs of starters in Swiss cheese during ripening. Samples were taken at $(a, c)$ day $0,(b)$ day 22 and $(d)$ day 69. $(a)$ Undamaged rod-shaped cells of Lactobacillus helveticus, $(b)$ damaged cells of $L b$. helveticus, $(c)$ mixed colony of intact $L b$. helveticus and Streptococcus thermophilus cells and $(d)$ cells of Propionibacterium freudenreichii exhibiting a coccoid morphology. Scale bars: $(a$, $b$, c) $5 \mu \mathrm{m},(d) 2 \mu \mathrm{m}$. 


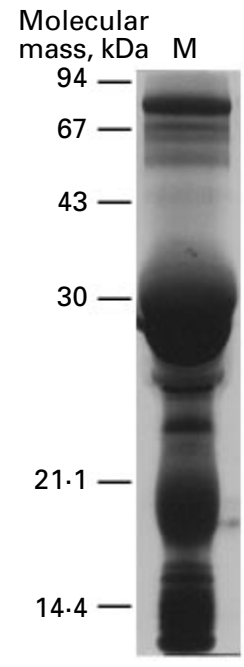

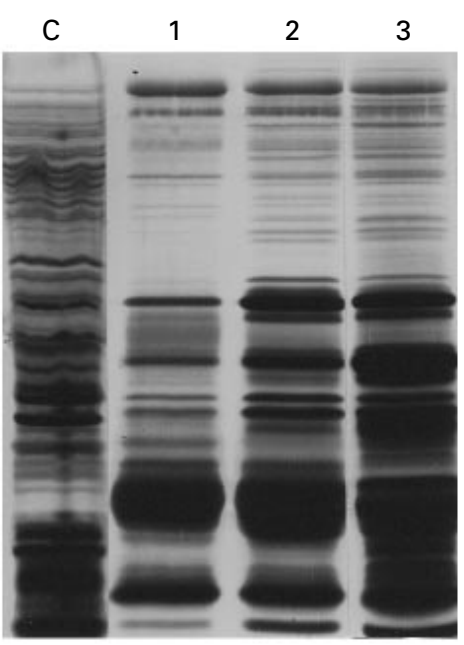

(a1)

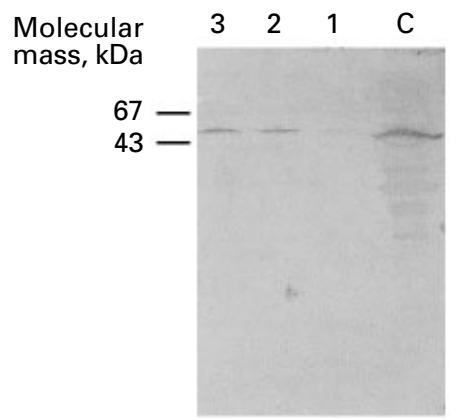

$(a 2)$

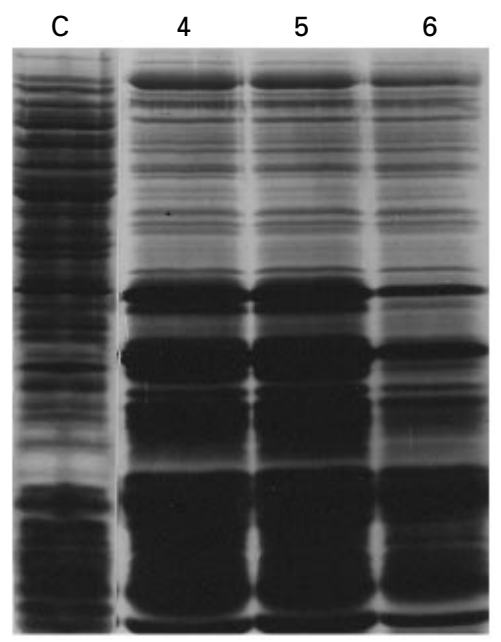

(b1)

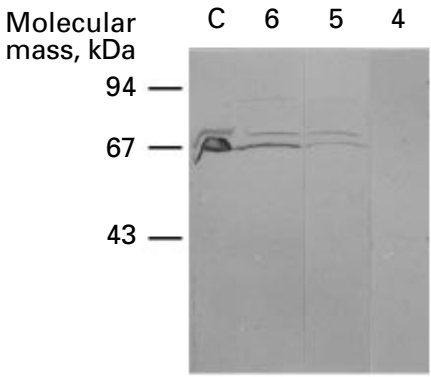

(b2)

Fig. 5. Autolysis of starter strains in experimental Swiss cheeses. (a1) SDS-PAGE and (a2) immunoblotting with anti-dipeptidase serum showing the autolysis of Lactobacillus helveticus by the early appearance of cytoplasmic proteins including dipeptidase in the aqueous cheese extracts: M, milk; C, LH77 crude cytoplasm; aqueous cheese extracts on : lane 1, day 0 ; lane 2 , day 16 ; lane 3 , day 22. (b1) SDS-PAGE and (b2) immunoblotting with anti-methylmalonyl coenzyme A mutase serum showing the late autolysis of Propionibacterium freudenreichii by the appearance of free methylmalonyl coenzyme A mutase in the aqueous cheese extracts only after cold storage of the cheeses: C, P23 crude cytoplasm; aqueous cheese extracts on : lane 4, day 69 ; lane 5 , day 76 ; lane 6 , day 92 . Molecular masses of standard proteins are indicated on the left.

freudenreichii $\mathrm{P} 23$ did not change during the cold room period but increased during warm room ripening to a maximum population of $2.5 \times 10^{9} \mathrm{cfu} / \mathrm{g}$ cheese. After that, no decrease in counts of Prop. freudenreichii was observed (Fig. 3). The macrorestriction profiles of 20 randomly sampled colonies from Pal Propiobac plates on day 69 were shown to be fully identical to Prop. freudenreichii P23.

Since the cheeses were made from microfiltered milk, the non-starter lactic flora was not detectable at the beginning of the ripening and did not exceed $10^{6} \mathrm{cfu} / \mathrm{g}$ at the end of the ripening.

\section{Appearance of bacteria in cheese}

Scanning electron microscopy revealed well-shaped lactobacilli at the beginning of the ripening process (Fig. $4 a$ ). It was notable that lactobacilli and streptococci were frequently mixed on the same colony (Fig. $4 c$ ). At day 22, damaged $L b$. 


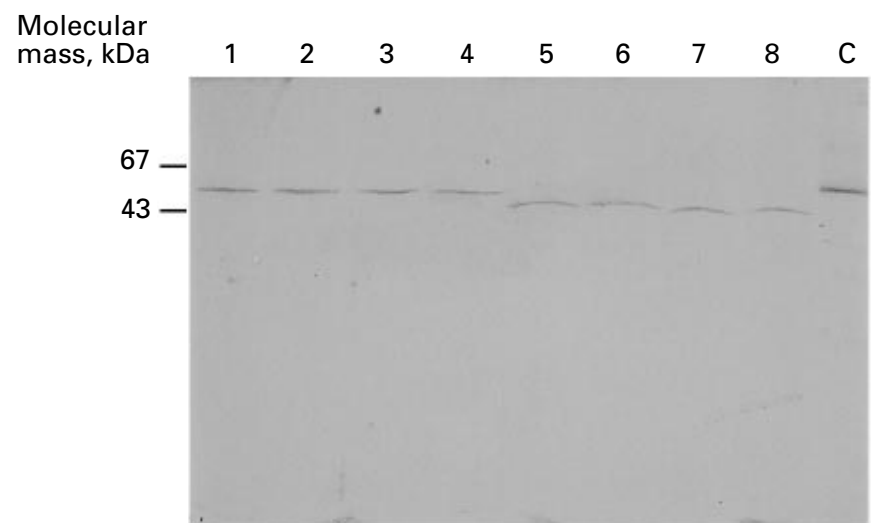

Fig. 6. Detection of dipeptidase lysis marker in commercial Swiss and related cheeses. Two extraction methods, standard (SM) and gentle (GM), were compared: lane 1, Parmesan GM; lane 2, Parmesan SM; lane 3, Comté GM; lane 4, Comté SM; lane 5, Beaufort GM; lane 6, Beaufort SM; lane 7, Emmental GM; lane 8, Emmental SM. C, LH77 crude cytoplasm. Molecular masses of standard proteins are indicated on the left.

helveticus LH77 cells were found (Fig. 4b), whereas the colonies of Prop. freudenreichii P23 appeared unchanged, i.e. coccoid and seemingly surrounded by polysaccharides throughout ripening (Fig. $4 d$ ).

Detection of the lysis markers in the experimental cheeses

Aqueous cheese extracts were first subjected to SDS-PAGE analysis and the protein profiles obtained were compared with protein profiles of $L b$. helveticus and Prop. freudenreichii cytoplasms and milk (Fig. 5). Between days 16 and 22, for an equal volume loaded per lane, we were able to detect an increase in the number of bands in cheese extracts, particularly for proteins with molecular masses $>30 \mathrm{kDa}$. As the milk SDS-PAGE profile did not contain proteins in the range $30-60 \mathrm{kDa}$, proteins detected in this size frame from cheese extracts most probably came from bacterial cells (Fig. $5 a, b$ ).

Results of the immunoblotting of cheese extracts with polyclonal PepD antibodies are shown in Fig. 5(a). PepD was detected in the cheese extracts as a faint signal on day 16 but in much higher quantities at the end of the cold room period (day 22). No variations in the intensity of PepD could be detected thereafter up to the end of ripening (results not shown). The standard aqueous extraction method involved an Ultra-Turrax step, which may have caused disruption of the weakened cells. However, the immunoblot profiles were exactly the same with the gentle aqueous extraction procedure developed in this study (results not shown). These results demonstrated that $L b$. helveticus undergoes autolysis at the beginning of ripening.

The immunoblotting analysis of the cheese extracts with polyclonal MMCoA antibodies did not allow the detection of lysis marker at the first attempt. However, a weak but clear signal from MMCoA was observed in 20 -fold concentrated standard and gentle extracts on day 76, indicating a weak autolysis of Prop. freudenreichii during cold storage after ripening (Fig. $5 b$ ).

Detection of the lysis markers in commercial Emmental, Beaufort, Comté and Parmesan cheese

Aqueous cheese extracts (standard and gentle extraction methods) of commercial Swiss and related cheeses obtained from a local supermarket were subjected to SDSPAGE and immunoblotting analyses. Regardless of the extraction method used, 
SDS-PAGE profiles in the different cheeses were very similar both to each other and to our experimental small scale cheeses (results not shown). For Parmesan and Comté cheeses, PepD was clearly detected, showing that $L b$. helveticus underwent autolysis (Fig. 6). With Emmental and Beaufort cheeses, only weak signals of a molecular mass slightly lower than that of $L b$. helveticus PepD were detected. The cross reacting band was identified as the $51 \mathrm{kDa}$ protein detected in the crude cytoplasm of $L b$. lactis, giving indications of autolysis of this species in these cheeses.

\section{DISCUSSION}

The autolysis of Lb. helveticus in Swiss cheese has been demonstrated for the first time in this study. The release of intracellular PepD occurred mainly during cold room ripening and was coincident with the decrease in lactobacilli counts and with the scanning electron microscopy observations of damaged cells. Whatever the method of extraction used (standard or gentle) the PepD appeared at the same time, indicating that bursting of weakened cells during the extraction procedure was unlikely. The presence of a very faint band of free PepD at the beginning of the cold room period, together with the $0 \cdot 3 \mathrm{log}$ reduction in counts during brining, could indicate that the autolysis of Lb. helveticus started just at the end of pressing. At this stage, Lb. helveticus encountered an effective nutrient starvation (depletion of galactose) at a $\mathrm{pH}(5 \cdot 4)$ and a temperature $\left(11^{\circ} \mathrm{C}\right)$ allowing the expression of the autolysins (Lortal et al. 1991). The detection of PepD in aqueous extracts from commercial Comté and Parmesan supported the idea that autolysis of Lb. helveticus is a general phenomenon in Swiss and related cheeses. This is in agreement with frequent observations of a decrease in thermophilic starter counts during the ripening of Swiss and related cheeses (Accolas et al. 1978; Coppola et al. 1997; Demarigny et al. 1996; Thierry et al. 1998). Nevertheless, before this is taken to be general, it should be verified for a larger number of $L b$. helveticus strains.

Secondary proteolysis (production of small peptides and free amino acids) is an essential step during ripening. Lb. helveticus possesses numerous intracellular peptidases and at least two of them (APII and APIV) have been claimed to be involved in processing bitter peptides (Prost \& Chamba, 1994). This implies not only their release in the curd through autolysis but also their ability to retain significant activity after being released. This is plausible, since it was recently shown that peptidases from thermophilic lactic species can retain their activity for several weeks in Emmental juice (Gagnaire et al. 1998). Moreover, various lactococcal intracellular enzymes, including peptidases, are stable in the cheese curd (Wilkinson et al. 1994b). Thus, the ability of Lb. helveticus to release its cytoplasmic content should be taken into consideration in starter selection. The extent of autolysis in the cheese probably depends on the strain and on the technological conditions (heating, brining, initial lactose content, $\mathrm{pH}$ ), but the strain dependence should be the most promising factor to study. Indeed, previous experiments in buffers, growth media and dairy substrates have underlined a significant variation in autolytic activity among Lb. helveticus strains (Ohmiya \& Sato, 1975; Bie \& Sjöström, 1975a,b; Lortal et al. $1997 a$ ).

In the case of Prop. freudenreichii, the main carbon source (lactate) was depleted from the middle of the warm room period. This represented nutrient starvation for $22 \mathrm{~d}$ at $\mathrm{pH} 5.5$ and $24^{\circ} \mathrm{C}$, conditions that usually induce autolysis (Lemée et al. 1994a). Nevertheless, autolysis of Prop. freudenreichii occurred very late, during cold storage, and its extent was apparently limited, since a concentration step of the cheese extracts was necessary to detect the MMCoA. At the same time, no significant 
reduction in counts was found, further supporting the idea of a very limited extent of autolysis for Prop. freudenreichii. The early autolysis of Lb. helveticus demonstrated in this study was much more likely to influence the ripening process and this is currently under investigation.

From a methodological point of view, the immunoblotting detection developed to monitor lysis has many advantages: it is adequately sensitive, it is possible to analyse several samples at the same time and it is not dependent on the enzymic activity of markers. Indeed the variations in activity were regarded as a subtle problem when enzymic lysis markers were used (Wilkinson et al. 1994b). Furthermore, taking into account their species specificity, the antisera anti-PepD and anti-MMCoA mutase could probably be used to detect the lysis of $L b$. helveticus and Prop. freudenreichii in other ecosystems.

We are deeply indebted to Dr Leadlay (University of Cambridge, Department of Biochemistry, Tennis Court Road, Cambridge, UK) for providing us with pure methylmalonyl coenzyme A mutase, and to E. Vesanto for the rabbit sera antiPepD. We sincerely thank M. Le Hénaff for advice on western-blotting analysis and S. Guezenec for skilled technical assistance.

\section{REFERENCES}

Accolas, J. P., Veaux, M., Vassal, L. \& Mocquot, G. 1978 [Development of the thermophilic lactic acid bacteria of hard cheese during pressing.] Lait $\mathbf{5 8} 118-132$

Berdagué, J.-L. 1986 [Rapid extraction of volatile free fatty acids from cheese.] Lait 66 233-246

Bie, R. \& Sлӧsтröm, G. 1975 a Autolytic properties of some lactic acid bacteria used in cheese production. I. Material and methods. Milchwissenschaft $30653-657$

BiE, R. \& Sлöströм, G. $1975 b$ Autolytic properties of some lactic acid bacteria used in cheese production. II. Experiments with fluid substrates and cheese. Milchwissenschaft $30739-747$

Boтtazzi, V. 1993 Aspects of lactic acid bacteria biology. I. Growth and lysis of Lactobacillus cells in cheese. In Biotechnology and Molecular Biology of Lactic Acid Bacteria for the Improvment of Foods and Feeds Quality, pp. 227-247 (Eds A. Zamorani, P. L. Manachini, V. Bottazzi and S. Coppola). Roma: Istituto Poligrafico e Zecca dello Stato.

Buisson, V., KerJean, J. R. \& Courroye, M. 1987 [Miniaturization of cheese technology.] Technique Laitière \& Marketing no. 1024 17-18, 20-23

Cappa, F., Bottazzi, V., Bosi, F. \& Parisi, M. G. 1997 Characterization of propionibacteria in Grana cheese. Scienza e Tecnica Lattiero-Caesaria 47 405-414

Сhapot-Chartier, M.-P., Deniel, C., Rousseau, M., Vassal, L. \& Gripon, J.-C. 1994 Autolysis of two strains of Lactococcus lactis during cheese ripening. International Dairy Journal 4 251-269

Coppola, R., Nanni, M., Iorizzo, M., Sorrentino, A., Sorrentino, E. \& Grazzia, L. 1997 Survey of lactic acid bacteria isolated during the advanced stages of the ripening of Parmigiano Reggiano cheese. Journal of Dairy Research 64 305-310

Crow, V. L., Coolbear, T., Gopal, P. K., Martley, F. G., McKay, L. L. \& Riepe, H. 1995a The role of autolysis of lactic acid bacteria in the ripening of cheese. International Dairy Journal 5 855-875

Crow, V. L., Martley, F. G., Coolbear, T. \& Roundhill, S. J. $1995 b$ The influence of phage-assisted lysis of Lactococcus lactis subsp. lactis ML8 on Cheddar cheese ripening. International Dairy Journal 5 451-472

Demarigny, Y., Beuvier, E., Dasen, A. \& Duboz, G. 1996 Influence of raw milk microflora on the characteristics of Swiss-type cheeses. I. Evolution of microflora during ripening and characterization of facultatively heterofermentative lactobacilli. Lait 76 371-387

Demeter, K. J., Janoschek, A. \& GüEnther, E. 1953 [Further details on the bacteriology of Emmental cheesemaking and ripening.] Milchwissenschaft $8420-426$

Dupuis, C. \& Boyaval, P. 1993 Esterase activity of dairy Propionibacterium. Lait 73 345-356

Gagnaire, V., Lortal, S. \& LÉonil, J. 1998 Free active peptidases are detected in Emmental juice extracted before ripening in the warm room. Journal of Dairy Research 65 119-128

Hansen, P. A. 1941 A study in cheese ripening. The influence of autolyzed cells of Streptococcus cremoris and Streptococcus lactis on the development of Lactobacillus casei. Journal of Dairy Science 24 969-976

Heiss, E. [Rapid methods for the determination of fat content of cheese.] Deutsche Molkerei-Zeitung 82 67-70

International Dairy Federation 1982 Cheese and Processed Cheese. Determination of the total solids content (reference method). Brussels: IDF (FIL-IDF Standard no. 4A)

International Dairy Federation 1988 Cheese and Processed Cheese Products. Determination of chloride content. Potentiometric method. Brussels: IDF (FIL-IDF Standard no. 88A) 
Isolini, D., Grand, M. \& GLätthi, H. 1990 [Selective media for enumeration of obligatory and facultative heterofermentative lactobacilli.] Schweizerische Milchwissenschaft und Forschung 19 57-59

Kawabata, S., Vassal, L., le Bars, D., Cesselin, B., Nardi, M., Gripon, J.-C. \& Сhapot-Chartier M.-P. 1997 Phage-induced lysis of Lactococcus lactis during Saint-Paulin cheese ripening and its impact on proteolysis. Lait $77229-239$

Kellermeyer, R. W., Allen, S. H. G., Stjernholm, R. \& Wood, H. G. 1964 Methylmalonyl isomerase. 4. Purification and properties of the enzyme from propionibacteria. Journal of Biological Chemistry 239 $2562-2569$

Kuchroo, C. N. \& Fox, P. F. 1982 Soluble nitrogen in Cheddar cheese: comparison of extraction procedures. Milchwissenschaft 37 331-335

La mmmLi, U. K. 1970 Cleavage of structural proteins during the assembly of the head of bacteriophage T4. Nature $227680-685$

Langsrud, T. \& Reinbold, G. W. 1973 Flavor development and microbiology of Swiss cheese - a review. II. Starters, manufacturing processes and procedures. Journal of Milk and Food Technology 36 531-542

Law, B. A., Sharpe, M. E. \& Reiter, B. 1974 The release of intracellular dipeptidase from starter streptococci during Cheddar cheese ripening. Journal of Dairy Research 41 137-146

Lemeé, R., Lortal, S., Cesselin, B. \& van HeiJenoort, J. 1994 a Involvement of an $N$-acetylglucosaminidase in autolysis of Propionibacterium freudenreichii CNRZ 725. Applied and Environmental Microbiology 60 $4351-4358$

Lortal, S., Lemeé, R. \& VAlence, F. 1997 a Autolysis of thermophilic lactobacilli and dairy propionibacteria: a review. Lait 77 133-150

Lemé, R., Rouault, A., Guezenec, S. \& Lortal, S. $1994 b$ Autolysis of 57 strains of dairy propionibacteria. Lait $74241-251$

Lortal, S., Rouault, A., Guezenec, S. \& Gautier, M. $1997 b$ Lactobacillus helveticus: strain typing and genome size estimation by pulsed field gel electrophoresis. Current Microbiology 34 180-185

Lortal, S., Rousseau, M., Boyaval, P. \& van Heijenoort, J. 1991 Cell wall and autolytic system of Lactobacillus helveticus ATCC 12046. Journal of General Microbiology 137 549-559

Malik, A. C., Reinbold, G. W. \& Vedamuthu, E. R. 1968 An evalution of the taxonomy of Propionibacterium. Canadian Journal of Microbiology 14 1185-1191

Marsh, E. N., McKie, N., Davis, N. K. \& Leadlay, P. F. 1989 Cloning and structural characterization of the genes coding for adenosylcobalamin-dependent methylmalonyl CoA mutase from Propionibacterium shermanii. Biochemical Journal $260345-352$

O'Donovan, C. M., Wilkinson, M. G., Guinee, T. P. \& Fox, P. F. 1996 An investigation of the autolytic properties of three lactococcal strains during cheese ripening. International Dairy Journal 6 1149-1165

Oнмiтa, K. \& Sato, Y. 1970 Studies on the proteolytic action of dairy lactic acid bacteria. X. Autolysis of lactic acid bacterial cells in aseptic rennet curd. Agricultural and Biological Chemistry 34 457-463

Онміуа, K. \& Sato, Y. 1975 Promotion of autolysis in lactobacilli. Agricultural and Biological Chemistry 39 $585-589$

Prost, F. \& Chamba, J. F. 1994 Effect of aminopeptidase activity of thermophilic lactobacilli on Emmental cheese characteristics. Journal of Dairy Science 77 24-33

Richoux, R. \& KeRJEAn, J. R. 1995 [Technological properties of pure propionibacteria strains : tests in small scale Swiss-type cheese.] Lait 75 45-59

Sandholm, E. \& Sarimo, S. S. 1981 Autolysis of Streptococcus thermophilus. FEMS Microbiology Letters 11 $125-129$

SASaki, M., Boosman, B. W. \& Tan, P. S. T. 1995 Comparison of proteolytic activities in various lactobacilli. Journal of Dairy Research 62 601-610

Syndicat Interprofessionel du Gruyère Français 1997 [Hard Cooked Cheeses: Statistics, 1996.] Paris: SIGF

Steffen, C., Eberhard, P., Bosset, J. O. \& Rügga, M. 1993 Swiss-type varieties. In Cheese: Chemistry, Physics and Microbiology, vol. 2, Major cheese groups, pp. 83-110 (Ed. P. F. Fox). London: Chapman \& Hall

Thierry, A., Salvat-Brunaud, D., Madec, M. N., Michel, F. \& Maubois, J.-L. 1998 [Swiss cheese ripening: dynamics of bacterial populations and evolution of the aqueous phase composition for three industrial cheeses.] Lait In press

Towbin, H., Staehelin, T. \& Gordon, J. 1979 Electrophoretic transfer of proteins from polyacrylamide gels to nitrocellulose sheets: procedure and some applications. Proceedings of the National Academy of Sciences, USA $764350-4354$

VALence, F. \& LoRTal, S. 1995 Zymogram and preliminary characterization of Lactobacillus helveticus autolysins. Applied and Environmental Microbiology 61 3391-3399

Vesanto, E., Peltoniemi, K., Purtsi, T., Steele, J. L. \& Palva, A. 1996 Molecular characterization, overexpression and purification of a novel dipeptidase from Lactobacillus helveticus. Applied Microbiology and Biotechnology $45638-645$

Wilkinson, M. G., Guinee, T. P. \& Fox, P. F. 1994 a Factors which may influence the determination of autolysis of starter bacteria during Cheddar cheese ripening. International Dairy Journal 4 141-160

Wilkinson, M. G., Guinee, T. P., O'Callaghan, D. M. \& Fox, P. F. $1994 b$ Autolysis and proteolysis in different strains of starter bacteria during Cheddar cheese ripening. Journal of Dairy Research 61 249-262 